\title{
DIRASAH
}

Volume 2, Number 2, Agustus 2019

p-ISSN: 2615-0212 | e-ISSN: 2621-2838

https://ejournal.iaifa.ac.id/index.php/dirasah

\begin{tabular}{|l|c|c|}
\hline Accepted: & Revised: & Published: \\
Maret 2019 & Juli 2019 & Agustus 2019 \\
\hline
\end{tabular}

\section{Pengaruh Metode Pembelajaran Collaboration Problem Solving terhadap Hasil Belajar Matematika Siswa dengan Mengendalikan IQ dan Motivasi Belajar}

\author{
Miksan Ansori \\ Institut Agama Islam Faqih Asy'ari Kediri, Indonesia \\ e-mail:ikhsan.aira@gmail.com
}

\begin{abstract}
This research aims to determine if there are differences in the teaching methods in statistical subjects to the learning outcomes if IQ and student motivation are controlled. With a population of all students of SMPI Al A'la, the samples in this study were as much as 60 students divided into 4 classes containing 15 students each. Treatment is given to teachers in D-class, namely administering the Collaboration Problem Solving learning method. The Dependent variables in this study are the outcomes of student learning, while the IQ and the learning motivation are used as covariate variables. The results showed that there is a significant difference in student learning outcomes given different learning methods if controlled IQ and motivation for learning. By conducting advanced tests with Tukey HSD method, it can also be known that the learning results obtained in class with the learning method of Collaboration Problem Solving have a significant difference compared to class A using method Learning lecture with a value of sig. 0.14, class $B$ uses an individual assignment method with a value of sig. 0.005, and class $C$ uses the method of learning discussions with the value of SIG. 0.004. If you see a difference in reality, then it can be known that the Collaboration Problem Solving learning method is applied to the D-class, providing the best learning outcomes compared to other methods.
\end{abstract}

Keyword: learning methods, Collaboration Problem Solving, IQ, learning motivation and learning outcomes 


\section{Pendahuluan}

Persoalan disintegrasi menjadi permasalahan aktual akhir-akhir ini. Ancaman disintegrasi bangsa menguat berbagai survei yang diinterpretasikan sebagai ancaman potensial terhadap perpecahan bangsa. Hasil survei Wahid Institute misalnya, memaparkan data hasil survei yang menyebutkan bahwa 59,9 $\%$ responden memiliki kelompok yang dibenci dengan alasan primordial maupun pilihan kepentingan praktis tertentu. ${ }^{1}$ Potensi perpecahan juga tampak nyata dengan meningkatnya jumlah konflik yang terjadi di masyarakat yang mengindikasikan dengan sangat kuat bahwa diintegrasi bangsa menjadi ancaman sangat potensial saat ini. Lihat saja data Institute Titian Perdamaian ${ }^{2}$ pada gambar 1.

Tentu saja permasalahan itu harus ditanggapi dan dipecahkan secara serius sebagai langkah nyata menjaga persatuan bangsa dan tetap menjunjung tinggi prinsip bhineka tunggal ika. Dalam tataran pendidikan upaya pencegahan disintegrasi bangsa dapat dimulai sejak dini sebagai bentuk penyelesaian masalah fundamental yang dimuai dari akar permasalahan itu timbul. Pendidikan dalam perspektif ini dipandang memiliki peran sangat strategis dalam upaya pencegahan disintegrasi bangsa. Salah satu upaya nyata adalah dengan

\section{Gambar 1. Rangking Intensitas Konflik Berdasarkan Isu}
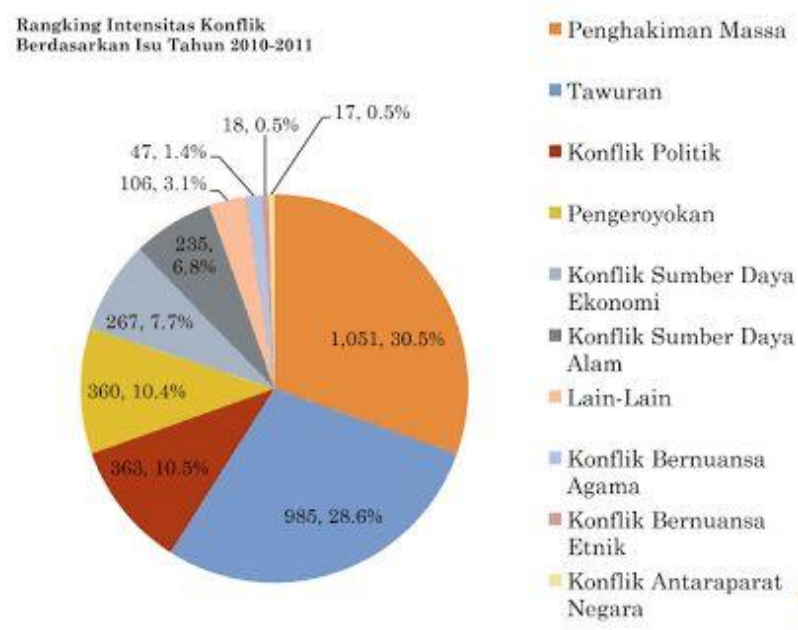

\footnotetext{
${ }^{1}$ Wahid Institute, Buku Laporan Riset Intoleransi dan Radikalisme di 4 Wilayah Wahid Institute. (Jakarta: Wahid Institute, 2016), 17

2 Institute Titian Perdamaian, Konflik Horisontal di Indonesia (Jakarta: Institute Titian Perdamaian, 2011), 23.
} 
menghadirkan proses pembelajaran yang menjunjung tinggi kolaborasi, kerja sama dan saling menghargai setiap individu yang ada dalam proses pembelajaran.

Kompetisi yang mengabaikan toleransi diyakini tumbuh sejak individu berada dalam lingkungan sekolah. Proses pembelajaran yang banyak menekankan unsur kompetisi dibandingkan kolaborasi membuat individu lebih sering bersaing dibandingkan bekerja sama. Lebih dari itu, individu juga 'dipaksa' mengalahkan lainnya dibandingkan menolong mereka. Individu yang tidak mampu bersaing akan dimarginalkan sedemikian rupa hingga membuat dirinya kehilangan percaya diri dan semakin tidak berkembang potensinya. Dalam satu titik tertentu, individu yang selalu memenangkan kompetisi jika menghadapi masalah kompleks yang tidak mungkin dipecahkannya sendiri, cenderung akan frustasi karena keengganan berkolaborasi dan memanfaatkan kemampuan di luar dirinya sendiri. Benih-benih egoisme dan individualisme yang tumbuh di lingkungan sekolah haruslah segera di reformasi. Penerapan proses pembelajaran yang menanamkan nilai-nilai kerja sama, saling menghargai dan menghormati, toleransi, menerima perbedaan, hendaknya ditanamkan dan dibiasakan sejak dini. Tanggung jawab semua pihak, seperti pendidik dan peneliti pendidikan, untuk menghadirkan pembelajaran positif bagi peserta didik dengan tidak menafikan tujuan pembelajaran utama. Dalam hal ini, salah satu tugas peneliti adalah menguji efektivitas dan dampak suatu penerapan metode tertentu dalam proses pembelajaran. Sedangkan pendidik diharapkan menerapkan pembelajaran yang mendukung penanaman sikap positif peserta didik.

Dalam banyak kajian, laporan dan penelitian oleh para ahli juga diungkap bahwa pendidikan saat ini belum cukup untuk mempersiapkan siswa dalam menghadapi kebutuhan tantangan kerja, perubahan ekonomi global, perubahan realitas sosial, cepatnya perkembangan teknologi yang melingkupi dunia kerja dan kehidupan serta kebutuhan untuk memberikan kompetensi dan skill prioritas yang harus dimiliki peserta didik di masa yang akan datang. Individu yang mudah bekerja sama dalam memecahkan suatu masalah bisa disebut bahwa dia memiliki collaborrative problem solving skill. Kemampuan CPS tersebut akhir-akhir ini banyak dikaji oleh para ahli dan organisasi-organisasi internasional seperti PISA dan ATC21S. Pembelajaran yang mengembangkan kemampuan Collaborative Problem Solving dapat menjadi jawaban atas fenomena tersebut. Mengingat banyaknya nilai-nilai inter personal dan intra personal yang dapat ditingkatkan dari individu dalam mendukung hubungan sosialnya sekarang maupun di masa 
yang akan datang (Ansori, 2018). ${ }^{3}$ Dua program internasional telah mengembangkan penilaian Collaborative Problem Solving, yaitu ATC21S (Assessment and Teaching of 21 st Century Skill) yang didukung oleh Cisco, Intel dan Mikrosoft; serta PISA (Programme for International Student Assessment) yang didukung oleh OECD (Organization for Economic Cooperation and Development). Hal itu membuktikan bahwa Collaborative Problem Solving menjadi isu utama saat ini dalam upaya mengatasi permasalahan pendidikan dan perkembangan zaman bagi peserta didik.

OECD juga menyebutkan bahwa CPS merupakan wilayah penelitian yang relatif baru dan banyak menarik peneliti, pendidik, ahli psikologi dan ahli-ahli lainnya. ${ }^{4}$ Ahli psikologi tertarik menjelaskan dan memahami proses CPS, Praktisi pendidikan tertarik untuk menerapkannya, dan peneliti (khususnya dalam bidang pembelajaran) tertarik untuk menguji efektivitas penerapannya. ${ }^{5}$

CPS sebagai sebuah metode pembelajaran terdiri dari dua unsur utama, yaitu collaborative learning dan problem solving. Interaksi sosial dalam collaborrative learning dikombinasikan dengan proses kerja kognitif dan metakognitif individu dalam memecahkan suatu masalah ${ }^{6}$. CPS dapat diterima secara luas oleh para ahli secara luas karena memiliki prinsip bahwa peserta didik harus mengembangkan kemampuan untuk mengkonstruk pemahaman melalui kolaborasi dengan orang lain sehingga peserta didik tersebut akan memahami orang lain dengan baik, serta dia juga akan membangun pengetahuan baru melalui proses pemecahan suatu masalah. ${ }^{7}$

3 M. Ansori, Terminologi dan Aspek-aspek Collaborative Problem Solving Skill's. Jurnal Dirasah, Volume 1, Nomor 2, 2018, 25-34.

${ }^{4}$ Griffin, P., McGaw, B., \& Care, E. (Eds.) (2012). Assessment and Teaching of 21 st Century Skills. Springer: Dordrecht. OECD (2013). Baca juga Draft PISA Collaborative Problem Solving Framework 2015.

${ }^{5}$ Claire Scoular, Esther Care and Nafisa Awwal, A Generalised Approach to Scoring Students Collaboration in Online: Game Environments. Proceedings of the European Conference on Games Based Learning. Academic Conferences \& Publishing International Ltd. 2016, 584.

${ }^{6}$ Xiaoqing Gu, Shan Chen, Wenbo Zhu, Lin Lin, an Intervention Framework Designed to Develop the Collaborative Problem-Solving Skills of Primary School Students. (New York: Springer, 2015), 143.

${ }^{7}$ K. Hogan, Thinking Aloud Together: a Test of an Intervention to Foster Students' Collaborative Scientific Reasoning. Journal of Research in Science Teaching, Vol. 36, No. 10 (1999), 10851109. Baca juga M. Scardamalia, C. Bereiter, \& M. Lamon, the CSILE Project: Trying to Bring the Classroom into World 3. In k. Mcgilly (ed.), Classroom Lessons: Integrating Cognitive Theory and Classroom Practice, (pp. 201-228). (Cambridge: MIT Press, 1994), 201-228.

Dirasah, Vol. 2, No. 2, Agustus 2019 
Dalam konteks keilmuan, kajian dan pengembangan kemampuan CPS masih terbatas dan sedikit dilakukan. Misalnya saja Ghu, Chen, Zhu dan Lin mengkaji mengenai CPS melalui kerangka kerja collaborative inquiry project yang menghasilkan hasil positif dan signifikan dalam meningkatkan kemampuan interpersonal dan pemecahan masalah siswa. ${ }^{8}$

Banyak kajian mengenai pembelajaran berbasis kolaborasi telah dilakukan oleh para ahli, praktisi serta akademisi. Banyak pula yang membuktikan efektivitasnya dalam meningkatkan nilai akademik maupun penanaman sikap positif peserta didik khususnya dalam aspek sikap inter personal seperti kemampuan saling menghargai, kerja sama, saling ketergantungan yang positif dan banyak lagi. Aspek-aspek positif tersebut tentu saja sangat dibutuhkan dalam bagi peserta didik dalam menjalani kehidupannya apalagi jika melihat perkembangan dan kondisi sosial saat ini yang cenderung sangat individual dan eksklusif. Individu yang sebelumnya menghadapi permasalahan yang lebih sederhana, saat ini harus dipaksa untuk memecahkan masalah yang lebih kompleks yang terkait dalam banyak hal. Kompleksitas permasalahan tersebut sering kali hanya dapat dipecahkan dengan kolaborasi berbagai individu. Jika ditarik resultante, maka perkembangan sosial yang mengarah pada sikap individual dan eksklusif justru kontra produktif jika harus dihadapkan pada permasalahan yang semakin hari semakin kompleks untuk dipecahkan.

Dalam penelitian ini menguji pengaruh metode pembelajaran Collaboration Problem Solving (D) terhadap hasil belajar siswa dibandingkan metode pembelajaran lainnya yang lebih bersifat kompetisi individual yaitu metode pembelajaran ceramah (A), metode penugasan individu (B), metode pembelajaran diskusi-presentasi individual (C). Tujuan dari penelitian ini adalah untuk mengetahui Apakah terdapat perbedaan hasil belajar yang signifikan siswa yang diajarkan dengan metode A, B, C dan D bila IQ dan motivasi belajar siswa dikendalikan. Selain itu penelitian ini juga memiliki tujuan untuk mengetahui metode pembelajaran yang manakah yang menghasilkan hasil belajar paling baik dibandingkan metode pembelajaran lainnya.

${ }^{8}$ Xiaoqing Gu, an Intervention., 143-159. 


\section{Terminologi Collaboration Problem Solving}

CPS terdiri dari dua konsep utama, yaitu collaboration dan problem solving. Dua konsep tersebut telah lama dan banyak dikaji para ilmuan secara parsial serta masing-masing dibahas secara mendalam. Pada level dasar, collaboration dapat dipahami sebagai bekerja sama. Dalam tataran ini, collaboration berarti kondisi kooperatif (menyetujui untuk bekerja bersamasama, banyak bagian yang berkontribusi), koordinasi sosial (adanya kesadaran bahwa pihak lain juga dapat berkontribusi yang pada akhirnya membentuk tingkah laku koordinatif). ${ }^{9}$ Tidak hanya itu, kolaborasi juga bermakna suatu pihak bekerja kepada suatu kesatuan untuk mencapai tujuan tertentu yang telah disetujui secara bersama dan sering kali mencocokkan ide-ide untuk membentuk suatu solusi dan keputusan tertentu. ${ }^{10}$

Littleton dan Mercer menyampaikan unsur-unsur yang menjadi kata kunci yang merujuk pada konsep kolaborasi, yaitu:

1. melaksanakan koordinasi, yang dilanjutkan dengan usaha untuk memecahkan masalah atau mengontruksi pengetahuan.

2. bekerja sama dengan komitmen: membagi tujuan, timbal balik, saling menguntungkan dan menelaah makna baru secara berkelanjutan

Dalam bentuk umumnya, yang dimaksud collaborative sebagai unsur pembentuk CPS terdiri collaborative learning (termasuk cooperative learning ${ }^{11}$ ) dan peer tutoring ${ }^{12}$. Dalam CPS, Nesta berpendapat bahwa peer tutoring tidaklah

${ }^{9}$ Nesta. Solve! Making the Case for Collaborative Problem Solving (London: SB Victoria Embankment, 2017), 11.

${ }^{10}$ Ibid.

${ }^{11}$ Cooperative learning (CL) berasal dari kata cooperative yang artinya mengerjakan sesuatu secara bersama sama dengan saling membantu satu sama lainnya sebagai satu kelompok atau satu tim. CL memungkinkan dalam sebuah kelompok belajar mampu menampilkan kontribusi setiap individu yang ada di dalamnya untuk meningkatkan kualitas dan mencapai tujuan pembelajaran. Baca R. T. Johnson, \& D. W. Johnson, An Overview of Cooperative Learning. (Baltimore: Brookes Press, 1994).

12 Sebagai sebuah metode pembelajaran peer tutoring dimaksudkan untuk menjembetani kesenjangan usia antara guru dan murid dengan meminta siswa lain yang sudah memahami materi untuk menjadi tutor bagi teman lainnya yang belum memahami sebuah matei pembelajaran. Tidak hanya bermanfaat untuk siswa yang dibimbing, peer tutoring juga diyakini mampu meningkatkan pemahaman pada diri siswa yang menjadi tutor sebayanya. Gordon dalam hal ini menguti ungkapan terkenal dari Canisius (1632) 'He who theaces others, teaches himself,. Baca Edward E. Gordon, Peer Tutoring: A Teacher's Resource Guide (Maryland: R\&L Education, 2005), 1. Baca juga Jennifer Sanders dan RebeccaL. Damron, They're All Writers: Theacing Peer Tutoring in the Elementary Writing Center (New York: Teacers College Pers, 2017). 9.

Dirasah, Vol. 2, No. 2, Agustus 2019 
relevan dengan tujuan CPS. Hal itu dikarenakan peer tutoring yang lebih ditujukan pada bagaimana siswa dengan performa tinggi membantu secara akademis siswa yang memiliki performa rendah untuk mereview konsep kritis akademis dan behavioris. ${ }^{13}$ Sedangkan coopertive learning masih sangat relevan dengan tujuan dari CPS. Hal itu dikarenakan dalam konteks cooperative learning kesuksesan individu juga linier dengan kesuksesan kelompok secara keseluruhan dan itu dapat dihasilkan dari tanggung jawab individu, saling ketergantungan positif serta kontribusi nyata setiap individu. ${ }^{14}$ Kompetensi sosial dan kognitif yang ingin dicapai dalam CPS juga selaras dengan penjelasan cooperative learning yang dikemukakan Slavin, yaitu perspektif sosial, kognitif dan elaborasi kognitif selain perspektif motivasi. ${ }^{15}$

Secara perspektif historis banyak penelitian mengenai collaorative dan cooperative berakar dari dua ahli, yaitu Piaget dan Vigotsky Contohnya adalah socio-constructivis meminjam teori Piaget mengenai tahap perkembangan yang menjelaskan progresifitas kognitif anak, juga ide mengenai konflik kognitif di mana kondisi disonansi pengalaman ketika seseorang menyadari sebuah dicrepancy antara latar kognitif yang ada pada dirinya dengan pengalaman dan informasi baru yang didapatnya. ${ }^{16}$ Sesuai dengan pendekatan sosio-constructivist konflik kognitif merupakan pemicu utama perkembangan kognitif seseorang. Interaksi sosial dengan orang lain membatu seseorang untuk lebih kompleks lagi menghadapi konflik kognitif tersebut sehingga terus berkembang tingkat kognitifnya. ${ }^{17}$ Berdasarkan hal tersebut maka, heterogenitas kelompok sangatlah dibutuhkan agar memiliki pengetahuan yang berbeda, skema representasi pengetahuan yang berbeda, dan perbedaan mekanisme argumentasi. ${ }^{18}$

Sedangkan Vigotsky lebih menekankan pada nilai-nilai interaksi sosial sendiri dalam menyebabkan perubahan kognitif individu, dibandingkan dengan

${ }^{13}$ Nesta. Solve! Making., 10.

${ }^{14}$ O. Korkmaz, A Validity and Reliabilitu Study of the Online Cooperative Learning Attitude Scale (OCLAS). Journal Computers \& Education. Vol. 59. No. 4. 2012. 1162-1169. http://dx.doi.org/10.1016/j.compedu.2012.05.021.

15 R.E. Slavin, Instructional Based on Cooperative Learning. (New York: John Hopkins University Press, 1995), 28.

16 P. Dillenbourg, M. Baker, A. Blaye, dan C. O’Malley, The evolution of research on collaborative learning. Dalam E. Spada \& P. Reiman (Eds.), Learning in humans and machine: Towards an interdisciplinary learning science (Oxford: Elsevier, 1996) . 189-211.

${ }^{17}$ Ibid.

${ }^{18}$ Emily R. Lai, Collaboration: A Literature Review. Pearson's Research Reports (2011), 8. 
hanya stimulus dari interaksi tesebut. ${ }^{19}$ Dalam pandangannya Vigotsky mengatakan bahwa nilai-nilai dari interaksi sosial akan diinternalisasi sehingga menyebabkan perubahan konseptual sebagai bentuk pemahaman baru. Sama halnya dengan Piaget, Vigotsky berpandangan bahwa perlunya heterogenitas anggota kelompok dalam sebuah bentuk kolaborasi. Hal inti dalam kolaborasi adalah perbedaan capaian ketika dia bekerja sendiri atau saat dia berinteraksi dengan orang lain yang lebih mampu. Dibandingkan harus berfokus pada konflik kognitif, kelompok socio-culture menganggap bahwa collaborative learning lebih dapat memunculkan perkembangan inti kognitif individu. ${ }^{20}$

Sementara itu, konsep kemampuan problem solving dapat dimaknai sebagai kemampuan individu untuk melakukan proses kognitif untuk memahami dan memecahkan permasalahan tertentu di mana metode pemecahan solusi tidak dapat diketemukan dengan jelas dan cepat. Marzano menjelaskan bahwa proses problem solving terjadi ketika pebelajar berusaha untuk mencapai suatu tujuan yang di dalamnya terdapat rintangan. ${ }^{21}$

Dalam problem solving, seorang siswa juga akan digugah untuk menggunakan pengetahuan relevan yang dimilikinya terhadap sebuah permasalahan dan meretrifikasi pengetahuan sebelumnya. Lebih jauh lagi dalam problem solving, siswa juga diharuskan mengidentifikasi halangan-halangan yang dihadapi dalam pemecahan masalah, mengevaluasi alternatif-alternatif yang dimiliki dan menyusun tindakan-tindakan yang dibutuhkan dalam mencapai tujuan melalui pemrosesan informasi yang diperolehnya kemudian memilih alternatif-alternatif tersebut untuk dilakukan tindakan yang berorientasi pada tujuan tertentu. ${ }^{22}$ Tentu saja aktivitas-aktivitas problem solving tersebut sangat berkaitan erat dengan kompetensi kognitif siswa. Berbeda dengan kompetensi kolaboratif yang dijelaskan sebelumnya, kompetensi kognitif berupa pemecahan masalah (problem soving) tidak berkaitan secara langsung dengan kompetensi inter personal yang dimilikinya karena sifatnya yang internal. Namun demikian, problem solving sendiri adakalanya dikerjakan seorang diri ada juga yang

${ }^{19}$ P. Dillenbourg, The Evolution., 189-211.

${ }^{20}$ Emily R., Collaboration., 9.

${ }^{21}$ Marzano juga mengungkapkan bahwa problem solving merupakan salah satu dari empat proses pemanfaat pengetahuan selain decision-making, Eksperimental Inquiry dan Investigation. Baca R.J. Marzano, Dimension of Thingking: a Framework of Curriculume and Instruction (Alexandria: The Association for Supervision and Curriculume Development, 1988), 12. Baca juga Helga A. H. Rowe, Problem Soving and intelligence (Hillsdale: Erlbaum, 1985).

22 Nesta. Solve! Making., 10.

Dirasah, Vol. 2, No. 2, Agustus 2019 
dikerjakan secara bersama-sama. Dalam konteks CPS, problem solving yang dilaksanakan lebih dari satu oranglah yang sesuai dengan tujuan CPS. Permasalahan sendiri muncul ketika seseorang memiliki tujuan tertentu namun dia tidak memiliki solusi yang cepat bagaimana mencapai tujuan tersebut. Mayer mendefinisikan problem solving sebagai proses kognitif yang diarahkan untuk mengubah situasi yang ada ke dalam situasi yang diinginkan ketika tidak adanya sebuah cara yang jelas tersedia. ${ }^{23}$ Oleh karenanya bisa juga dikatakan bahwa proses pemecahan masalah merupakan proses pencarian dan penyediaan sebuah alternatif cara penyelesaian yang jelas dengan tujuan untuk mencapai hasil yang diharapkan. Seperti yang telah dijelaskan sebelumnya, OECD lebih lanjut memaparkan bahwa problem solving sebagai sebuah kompetensi dapat dimaknai sebagai Sementara itu, konsep kemampuan problem solving dapat dimaknai sebagai kemampuan individu untuk melakukan proses kognitif untuk memahami dan memecahkan permasalahan tertentu di mana metode pemecahan solusi tidak dapat diketemukan dengan jelas dan cepat. ${ }^{24}$

Perpaduan dua konsep tersebut (collaborative dan problem solving) secara terminologi membentuk membentuk konsep baru, yakni collaborative problem solving, di mana istilah ini memiliki kesamaan terma dengan collaborative problem based learning atau collaborative inquiry based learning. Sifat dari sebuah masalah yang dihadapi membutuhkan berbagai sumber daya yang memiliki relevansi untuk dijadikan sebuah resolusi. Berbagai sumber daya tersebut bisa jadi berupa kemampuan dan pengetahuan yang dibawa masingmasing siswa tahu bisa juga berbagai sumber daya yang sifatnya fisik dan praktis $^{25}$.

\section{Metode Penelitian}

Jenis penelitian ini adalah penelitian kuantitatif yang berfokus pada objektivitas dan mengangkakan sebuah hakikat fenomena berdasarkan sebuah

\footnotetext{
${ }^{23}$ R.E. Mayer, "Problem solving", in Eysenck, M.W. (ed.), The Blackwell Dictionary of Cognitive Psychology, (Blackwell: Oxford Press, 1990), 284.

24 OECD (2010), PISA 2012 Field Trial Problem Solving Framework, http://www.oecd.org/dataoecd/8/42/46962005.pdf

${ }^{25}$ Claire Scoular, Esther Care dan Friedrich W. Hesse Designs for Operationalizing Collaborative Problem Solving for Automated Assessment. Journal of Educational Measurement, Vol. 54, No. 1, (2017). 12-35.
} 
investigasi atau membangun dan membuktikan sebuah teori (Schreiber \& Asnerself, 2011). ${ }^{26}$

Dengan menggunakan analisis kovarians faktorial $4 \times 2$, penelitian ini ingin menguji hasil belajar statistika siswa yang dihasilkan dari empat metode pembelajaran yang berbeda, motivasi belajar (MB) dan IQ siswa ditambahkan sebagai variabel kovariat. Rancangan penelitian dapat dilihat pada tabel di bawah ini:

Tabel 1. Rancangan tabel untuk anakova

\begin{tabular}{|l|l|l|l|l|l|l|l|l|l|l|l|l|}
\hline \multirow{2}{*}{ No. } & \multicolumn{3}{|l|}{ Metode A } & \multicolumn{3}{l|}{ Metode B } & \multicolumn{3}{l|}{ Metode C } & \multicolumn{3}{l|}{ Metode D } \\
\cline { 2 - 12 } & HB & IQ & MB & HB & IQ & MB & HB & IQ & MB & HB & IQ & MB \\
\hline 1 & & & & & & & & & & & & \\
\hline 2 & & & & & & & & & & & & \\
\hline 3 & & & & & & & & & & & & \\
\hline N & & & & & & & & & & & & \\
\hline
\end{tabular}

Populasi dalam penelitian ini adalah seluruh siswa SMPI Al A'la. Sedangkan sampel yang dipilih ada 60 siswa yang dibagi dalam 4 kelompok kelas yang masing-masing berisi 15 orang siswa. Pada salah satu kelompok, yaitu kelas D merupakan kelompok treatment. Pengujian analisis menggunakan analisis kovariansi untuk mengetahu ada tidaknya perbedaan yang signifikan metode pembelajaran terhadap hasil belajar setelah dikendalikan IQ dan motivasi belajarnya. Sebelum dilakukan analisis kovariansi, dilakukan uji asumsi normalitas dan uji homogenitas variansi.(Ansori dkk., 2013) ${ }^{27}$ Untuk memudahkan proses perhitungan, analisis data dibantu dengan program statistik SPSS 16.0.

${ }^{26}$ Schreiber \& Asner-self. Educational Research : Interrelationship of Questions, Sampling, Design, and Analysis (USA: John Wiley \& Sons, Inc, 2011), 13.

27 Ansori dkk. (2013). Efektivitas Pembelajaran Hypermedia Dan Slide Powerpoint. Jurnal Teknologi Pendidikan Dan Pembelajaran, 1(3), 321-336.

Dirasah, Vol. 2, No. 2, Agustus 2019 


\section{Hipotesis Penelitian}

Hipotesis yang diajukan dalam penelitian ini adalah

Ho : Tidak terdapat perbedaan yang signifikan metode pembelajaran (kelas A, B, C dan D) terhadap hasil belajar siswa jika IQ dan motivasi belajarnya dikendalikan.

Ha : Terdapat perbedaan yang signifikan metode pembelajaran (kelas A, B, C dan D) terhadap hasil belajar siswa jika IQ dan motivasi belajarnya dikendalikan.

\section{Hasil Penelitian}

Setelah melakukan pengumpulan data terhadap 60 sampel yang digunakan, kemudian dilanjutkan dengan analisis data dengan menggunakan program SPSS. Data statistik deskriptif masing-masing variabel dapat dilihat pada hasil out put sebagai berikut:

Tabel 2. Data statistik deskriptif masing-masing variabel Descriptive Statistics

\begin{tabular}{lrrrrr}
\hline & N & Minimum & \multicolumn{1}{c}{ Maximum } & \multicolumn{1}{c}{ Mean } & \multicolumn{1}{c}{ Std. Deviation } \\
\hline Metode & 60 & 1.00 & 4.00 & 2.5000 & 1.12747 \\
IQ & 60 & 52.00 & 73.00 & 60.7500 & 4.45172 \\
MB & 60 & 62.00 & 82.00 & 70.2500 & 4.10302 \\
HB & 60 & 65.00 & 85.00 & 72.8667 & 3.58654 \\
Valid N & 60 & & & & \\
(listwise) & & & & & \\
\hline
\end{tabular}

\section{Deskripsi variabel penelitian IQ}

Berdasarkan hasil out put SPSS dapat diketahui bahwa jumlah sampel sebanyak 60 siswa, rentang nilai 21, nilai minimum 52 dan maksimum 73 dengan rata-rata 60,75 dan standar deviasi 4,45. Gambar histogram variabel IQ disajikan sebagai berikut: 


\section{Gambar 2. Gambar histogram variabel IQ}

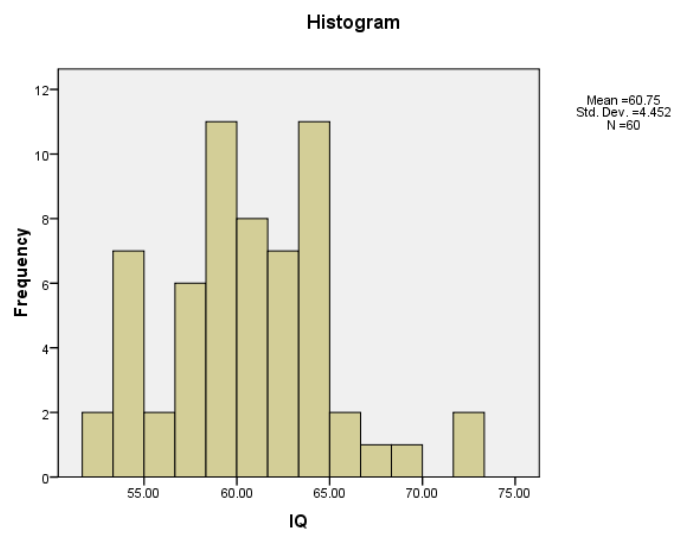

Deskripsi variabel penelitian Motivasi Belajar (MB)

Berdasarkan hasil out put SPSS dapat diketahui bahwa jumlah sampel sebanyak 60 siswa, rentang nilai 20, nilai minimum 22 dan maksimum 82 dengan rata-rata 70,25 dan standar deviasi 4,10. gambar histogram variabel MB disajikan sebagai berikut:

\section{Gambar 3. histogram variabel Motivasi Belajar}

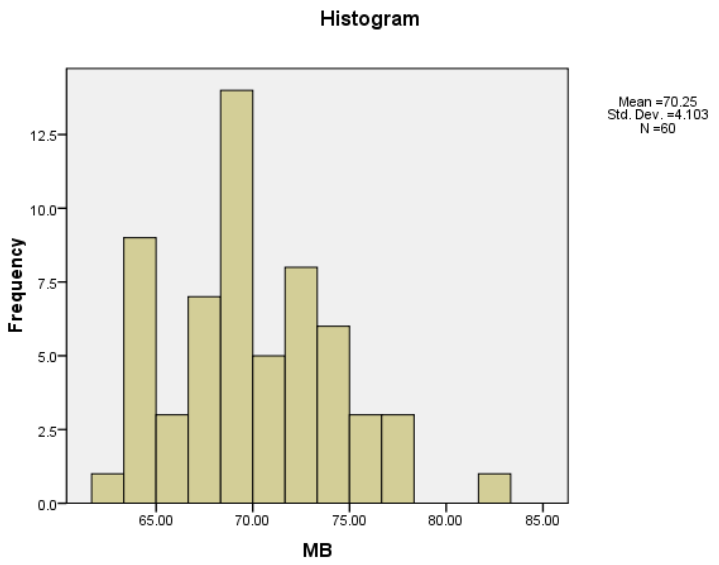

Dirasah, Vol. 2, No. 2, Agustus 2019 


\section{Deskripsi variabel penelitian Hasil Belajar (HB)}

Berdasarkan hasil out put SPSS dapat diketahui bahwa jumlah sampel sebanyak 60 siswa, rentang nilai 20, nilai minimum 65 dan maksimum 85 dengan rata-rata 72,87 dan standart deviasi 3,59. Tabel histogram variabel HB disajikan sebagai berikut:

\section{Gambar 4. histogram variabel Hasil Belajar}

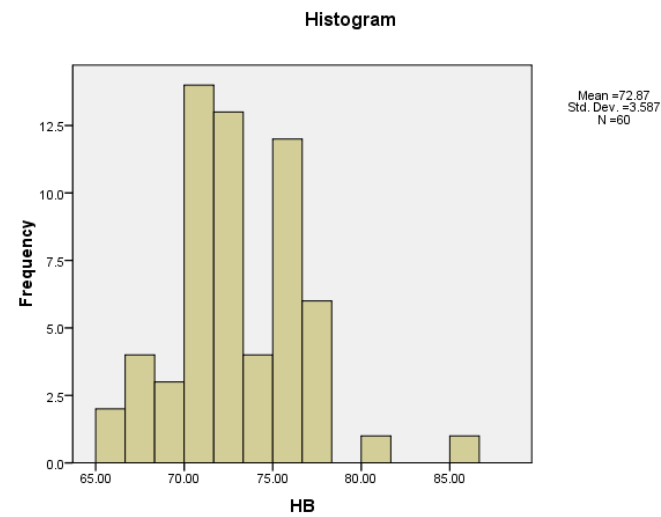

\section{Hasil Analisis Data dan Pegujian Hipotesis}

\section{Uji asumsi anakova}

Setelah diketahui data statistik deskriptif, langkah selanjutnya adalah melakukan uji asumsi analisis variansi dengan melakukan uji normalitas dan homogenitas variansi. Kedua uji asumsi dilakukan dengan SPSS dengan out put sebagai berikut:

\section{Uji normalitas data}

Sebagaimana dijelaskan sebelumnya, salah satu persyaratan uji analisis ANACOVA, data variabel, yaitu hasil belajar, IQ dan motivasi belajar siswa di dalam setiap kelompok (group), baik kelas kelompok eksperimen maupun kelas kelompok kontrol harus berdistribusi normal. Secara teoretis, sebetulnya banyak cara untuk menguji normalitas data. Berbagai buku statistik telah menyediakan informasi secara lengkap. Uji normalitas data penelitian ini menggunakan Software SPSS (Statistical Package for Social Science) for Windows versi 16.0. Formula yang digunakan untuk menguji normalitas data adalah uji Kolmogorov-Smirnov sebagai koreksi. Hasil uji normalitas data dipaparkan pada Tabel di bawah ini. 


\section{Tabel 3. Statistik Hasil Uji Normalitas Data}

One-Sample Kolmogorov-Smirnov Test

\begin{tabular}{llrrr}
\hline & & HB & IQ & \multicolumn{1}{c}{ MB } \\
\hline N & & 60 & 60 & 60 \\
Normal Parameters & Mean & 72.8667 & 60.75 & 70.25 \\
& Std. Deviation & 3.58654 & 4.45172 & 4.10302 \\
Most Extreme Differences & Absolute & .085 & .083 & .091 \\
& Positive & .085 & .078 & .091 \\
& Negative & -.062 & -.083 & -.059 \\
Kolmogorov-Smirnov Z & & .660 & .644 & .705 \\
Asymp. Sig. (2-tailed) & & .777 & .802 & .704 \\
\hline
\end{tabular}

a. Test distribution is Normal.

Berdasarkan analisis statistik sebagaimana tercantum dalam Tabel 3, tampak bahwa koefisien Kolmogorof-Smirnov pada variabel hasil belajar = 0,660 (sig. $=0,777$ ), nilai statistik tersebut signifikan pada $\mathrm{p}<0,05$. Berdasarkan signifikansi tersebut, maka hipotesis yang menyatakan bahwa "data penelitian tidak berdistribusi normal" ditolak. Kesimpulannya, data hasil penelitian yang berupa skor hasil belajar siswa berdistribusi normal. Hal yang sama juga terjadi pada variabel kovariat, yaitu IQ dan motivasi belajar. Koefisien Kolmogorof-Smirnov pada variabel IQ $=0,644$ (sig. $=0,802)$ dan motivasi belajar 0,705 (sig.=0,704), dan nilai statistik tersebut signifikan pada $\mathrm{p}<0,05$. Berdasarkan signifikansi tersebut, maka hipotesis yang menyatakan bahwa "data penelitian tidak berdistribusi normal" ditolak. Kesimpulannya, data hasil penelitian yang berupa IQ dan motivasi belajar siswa berdistribusi normal. Oleh karena itu, persyaratan normalitas data untuk memenuhi asumsi analisis two way ANOVA terpenuhi.

\section{Uji Homogenitas Varians}

Sama dengan persyaratan normalitas data, analisis ANACOVA juga harus memenuhi asumsi bahwa setiap sampel dari populasi harus memiliki varians yang sama (homogenity of variance) agar perbedaan yang ada bukan disebabkan oleh adanya perbedaan data dasar (heterogenitas kelompok yang dibandingkan), melainkan karena perlakuan dan karakteristik subjek yang berbeda. Pada Software SPSS (Statistical Package for Social Science) for Windows versi 16.0, formula yang dipilih (digunakan) untuk uji 
homogenitas varians adalah uji Levene. Secara teoretis, dalam uji Levene data ditransformasikan dengan jalan mencari selisih masing-masing skor dengan rerata kelompoknya. Hasil uji homogenitas varians dipaparkan dalam Tabel berikut ini.

\section{Tabel 4. Hasil Uji Homogenitas Varians}

Levene's Test of $\mathbf{E}$ quality of Error Variances ${ }^{\mathrm{a}}$

Dependent Variable:HB

\begin{tabular}{cccc}
\hline F & df1 & df2 & Sig. \\
\hline .618 & 3 & 56 & .606 \\
\hline $\begin{array}{l}\text { Tests the null hypothesis that the error variance of the } \\
\text { dependent variable is equal across groups. }\end{array}$
\end{tabular}

a. Design: Intercept $+\mathrm{IQ}+\mathrm{MB}+$ dosen

Berdasarkan tabel di atas tampak bahwa koefisien $\mathrm{F}$ tes $=0,618$ tidak signifikan karena $\mathrm{p}=0,606>0,05$. Hal itu berarti hipotesis yang menyatakan bahwa "tidak ada perbedaan varians antarkelompok subjek" diterima. Kesimpulannya, varians masing-masing kelompok, baik varians kelas kelompok eksperimen maupun varians kelas kelompok kontrol bersifat homogen (tidak berbeda). Mengingat kesamaan varians antar kelompok, maka dapat dijelaskan bahwa data penelitian sudah memenuhi asumsi uji analisis ANACOVA. 


\section{Pengujian Hipotesis dan Pembahasan}

Dengan melakukan analisis kovariansi menggunakan program SPSS diperoleh hasil out put sebagai berikut:

\section{Tabel 5. Statistik Hasil Uji Homogenitas Varians}

Tests of Between-Subjects Effects

Dependent Variable:HB

\begin{tabular}{lrrrrr}
\hline Source & Type III Sum of Squares & df & Mean Square & \multicolumn{1}{c}{ F } & \multicolumn{1}{l}{ Sig. } \\
\hline Corrected Model & $636.430^{\mathrm{a}}$ & 5 & 127.286 & 56.108 & .000 \\
Intercept & 57.325 & 1 & 57.325 & 25.269 & .000 \\
IQ & .468 & 1 & .468 & .206 & .652 \\
MB & 90.847 & 1 & 90.847 & 40.046 & .000 \\
Metode & 28.702 & 3 & 9.567 & 4.217 & .009 \\
Error & 122.503 & 54 & 2.269 & & \\
Total & 319332.000 & 60 & & & \\
Corrected Total & 758.933 & 59 & & & \\
\hline
\end{tabular}

a. $\mathrm{R}$ Squared $=, 839$ (Adjusted $\mathrm{R}$ Squared $=, 824$ )

Berdasarkan tabel Tests of Between-Subjects Effects di atas dapat diketahui bahwa hasil uji F hasil belajar antara metode memiliki nilai sebesar 4,217 dengan sig. sebesar 0,009. Karena sig. kurang dari taraf signifikansi $(\alpha)$ sebesar 0,05, maka dapat disimpulkan bahwa Ho ditolak dan Ha diterima, atau dengan kata lain terdapat perbedaan yang signifikan hasil belajar siswa yang diberikan 4 metode yang berbeda jika dikendalikan IQ dan motivasi belajarnya. Hasil pengujian hipotesis ini selaras dengan penelitian Wiley yang menemukan bahwa penerapan metode collaborative problem solving memberikan hasil yang berbeda bila dibandingkan dengan hasil belajar menggunakan metode nonkolaborasi (pembelajaran individual) ${ }^{28}$. Penelitian lain oleh Leo mengungkapkan hal yang sama. Dalam penelitiannya, Case menyebutkan bahwa siswa dapat secara signifikan memecahkan masalah dalam sebuah kelompok belajar kolaboratif dibandingkan ketika mereka memecahkan sebuah permasalahan tugas pembelajaran sendiri. Siswa Hazmat Holiday Special sebagai objek penelitian eksperimen dalam pembelajaran kolaboratif kelompok, sukses dan efisien menyelesaikan suatu kasus tambahan untuk masalah yang sama. Selain itu juga terdapat korelasi langsung antara strategi yang digunakan oleh

\footnotetext{
${ }^{28}$ Hilda Ives Wiley, Collaborative Problem-Solving Teams: The Relationship between Team Effectiveness And Teacher Attitudes, Beliefs, And Concerns, Tesis. The University Of Minnesota: 2006, 86.
}

Dirasah, Vol. 2, No. 2, Agustus 2019 
kelompok-kelompok kolaboratif dan strategi yang digunakan para siswa dalam setiap kelompok. ${ }^{29}$

Selanjutnya dengan melihat nilai $\mathrm{F}$ hitung variabel kovariatnya, yaitu IQ = 0,206 (sig. 0,652) dan motivasi belajar $=40,046$ (sig. 0,000), maka dapat diketahui bahwa variabel kovariat IQ tidak memiliki pengaruh secara signifikan terhadap hasil belajar, sedangkan variabel motivasi belajar memiliki pengaruh yang signifikan terhadap hasil belajar mahasiswa. Dari tabel di atas juga menunjukkan bahwa nilai $F_{\text {hitung }}$ corrected model sebesar 56,108 (sig. 0,000) dengan taraf signifikansi 5\% maka dapat disimpulkan bahwa semua variabel independen mempengaruhi variabel dependennya. Nilai $R$ Squared $=, 839$ (Adjusted $R$ Squared = ,824) menunjukkan bahwa 82,4\% hasil belajar siswa dipengaruhi oleh variabel-variabel independennya, sedangkan 17,6\% lainnya dipengaruhi variabel lain yang tidak dijelaskan dalam penelitian ini.

Apabila tidak menyertakan variabel kovariat, maka hasil komputasi seperti pada tabel Tabel 7. Tests of Between-Subjects Effects.

\section{Tabel 7. Tests of Between-Subjects Effects}

Dependent Variable:HB

\begin{tabular}{lrrrrr}
\hline Source & $\begin{array}{c}\text { Type III Sum of } \\
\text { Squares }\end{array}$ & df & Mean Square & \multicolumn{1}{c}{ F } & \multicolumn{1}{c}{ Sig. } \\
\hline Corrected Model & $182.533^{\mathrm{a}}$ & 3 & 60.844 & 5.911 & .001 \\
Intercept & 318573.067 & 1 & 318573.067 & $3.095 \mathrm{E} 4$ & .000 \\
Metode & 182.533 & 3 & 60.844 & 5.911 & .001 \\
Error & 576.400 & 56 & 10.293 & & \\
Total & 319332.000 & 60 & & & \\
Corrected Total & 758.933 & 59 & & & \\
\hline
\end{tabular}

a. $\mathrm{R}$ Squared = ,241 (Adjusted R Squared $=, 200$ )

Hasil tersebut menunjukkan bahwa dengan tidak adanya variabel kovariat IQ dan MB, metode pembelajaran yang berbeda tetap menghasilkan hasil belajar siswa yang sama. Hal tersebut dapat dijelaskan sebab tingginya perbedaan hasil belajar yang dihasilkan salah satu dosen dalam kelas tertentu.

Untuk mengetahui kelas mana yang menghasilkan hasil belajar yang paling baik maka dapat digunakan uji Tukey seperti pada tabel 8. Berdasarkan output uji Tukey maka dapat diketahui bahwa Metode D memiliki hasil belajar yang

${ }^{29}$ Edward Leo Case, The Effects pf Collaborative Grouping on Student Problem Solving in First Year ChemIstry, Disertasi. Clemson University: 2004, 79.

Dirasah, Vol. 2, No. 2, Agustus 2019 
berbeda secara signifikan dibandingkan kelas lainnya. Hasil belajar yang diberikan oleh metode $\mathrm{D}$ memiliki perbedaan yang signifikan dibandingkan metode A dengan nilai sig. 0,14 (taraf signifikansi 0,05), Metode B dengan nilai sig. 0,005 (taraf signifikansi 0,05), dan metode $\mathrm{C}$ dengan nilai sig. 0,004. Jika melihat perbedaan reratanya, maka dapat diketahui bahwa metode $\mathrm{D}$ memberikan hasil belajar yang paling baik dibandingkan metode-metode yang lain. Metode D (collaborative problem solving) yang menghasilkan hasil belajar yang signifikan dalam penelitian ini juga mendukung penelitian Stevens Case \& Cooper yang melakukan penelitian eksperimen menggunakan media Interactive Multi-Media Exercises $(I M M E X)^{30}$.

\section{Tabel 8. Tests of Tukey \\ Multiple Comparisons}

Dependent Variable:HB

\begin{tabular}{|c|c|c|c|c|c|c|c|}
\hline & \multirow[b]{2}{*}{ (I) METODE } & \multirow[b]{2}{*}{ (J) METODE } & \multirow{2}{*}{$\begin{array}{c}\text { Mean } \\
\text { Difference } \\
(\mathrm{I}-\mathrm{J})\end{array}$} & \multirow[b]{2}{*}{ Std. Error } & \multirow[b]{2}{*}{ Sig. } & \multicolumn{2}{|c|}{ 95\% Confidence Interval } \\
\hline & & & & & & $\begin{array}{l}\text { Lower } \\
\text { Bound }\end{array}$ & $\begin{array}{l}\text { Upper } \\
\text { Bound }\end{array}$ \\
\hline \multirow{12}{*}{$\begin{array}{l}\text { Tukey } \\
\text { HSD }\end{array}$} & \multirow[t]{3}{*}{$\bar{A}$} & B & .4667 & 1.17149 & .978 & -2.6353 & 3.5686 \\
\hline & & $\mathrm{C}$ & .5333 & 1.17149 & 968 & -2.5686 & 3.6353 \\
\hline & & $\mathrm{D}$ & $-3.6667^{*}$ & 1.17149 & .014 & -6.7686 & -.5647 \\
\hline & \multirow[t]{3}{*}{ B } & A & -.4667 & 1.17149 & .978 & -3.5686 & 2.6353 \\
\hline & & $\mathrm{C}$ & .0667 & 1.17149 & 1.000 & -3.0353 & 3.1686 \\
\hline & & $\mathrm{D}$ & $-4.1333^{*}$ & 1.17149 & .005 & -7.2353 & -1.0314 \\
\hline & \multirow[t]{3}{*}{$\bar{C}$} & A & -.5333 & 1.17149 & .968 & -3.6353 & 2.5686 \\
\hline & & B & -.0667 & 1.17149 & 1.000 & -3.1686 & 3.0353 \\
\hline & & D & $-4.2000^{*}$ & 1.17149 & .004 & -7.3020 & -1.0980 \\
\hline & \multirow[t]{3}{*}{$\overline{\mathrm{D}}$} & $\bar{A}$ & $3.6667^{*}$ & 1.17149 & .014 & .5647 & $\overline{6.7686}$ \\
\hline & & B & $4.1333^{*}$ & 1.17149 & .005 & 1.0314 & 7.2353 \\
\hline & & $\mathrm{C}$ & $4.2000^{*}$ & 1.17149 & .004 & 1.0980 & 7.3020 \\
\hline
\end{tabular}

Based on observed means.

The error term is Mean Square(Error) $=10,293$.

${ }^{30}$ a web-based software package that can deliver multiple cases of case-based problems and keep track of the information students use in solving the problems. Analysis of this tracking data provides insight into the strategies being employed by students. Case, B. E., Stevens, R., \& Cooper, M. (2000). Is Collaborative Grouping an Effective Instructional Strategy? Journal of College Science Teaching. Volume 8, Nomor 4, 2000, 42.

Dirasah, Vol. 2, No. 2, Agustus 2019 


\section{Penutup}

Berdasarkan analisis data yang telah dilakukan, maka penelitian ini dapat menyimpulkan bahwa:

1. Terdapat perbedaan yang signifikan hasil belajar siswa yang diberikan 4 metode yang berbeda jika dikendalikan IQ dan motivasi belajarnya. Dengan

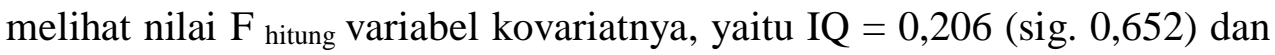
motivasi belajar $=40,046(0,000)$, maka dapat diketahui bahwa variabel kovariat IQ tidak memiliki pengaruh secara signifikan terhadap hasil belajar, sedangkan variabel motivasi belajar memiliki pengaruh yang signifikan terhadap hasil belajar mahasiswa. Dari tabel di atas juga menunjukkan bahwa nilai Fhitung corrected model sebesar 56,108 (sig. 0,000) dengan taraf signifikansi 5\% maka dapat disimpulkan bahwa semua variabel independen mempengaruhi variabel dependennya. Nilai $R$ Squared $=, 839$ (Adjusted $R$ Squared $=, 824)$ menunjukkan bahwa $82,4 \%$ hasil belajar siswa dipengaruhi oleh variabel-variabel independennya, sedangkan $17,6 \%$ lainnya dipengaruhi variabel lain yang tidak dijelaskan dalam penelitian ini.

2. Hasil belajar yang dihasilkan oleh metode collaborative problem solving (D) memiliki perbedaan yang signifikan dibandingkan metode A dengan nilai sig. 0,14 (taraf signifikansi 0,05), metode B dengan nilai sig. 0,005 (taraf signifikansi 0,05), dan metode dengan nilai sig. 0,004. Jika melihat perbedaan reratanya, maka dapat diketahui bahwa metode D memberikan hasil belajar yang paling baik dibandingkan metode-metode yang lain.

\section{Daftar Pustaka}

Ansori, M.. Terminologi dan Aspek-aspek Collaborative Problem Solving Skill's. JURNAL DIRASAH, 1(2). 2018. 25-34. Retrieved from https://ejournal.stisfa-kediri.ac.id/index.php/dirasah/article/view/10

Case, B. E., Stevens, R., \& Cooper, M. Is Collaborative Grouping an Effective Instructional Strategy? Journal of College Science Teaching. Volume 8, Nomor 4. 2000.

Case, Edward Leo. The Effects pf Collaborative Grouping on Student Problem Solving in First Year ChemIstry, Disertasi. Clemson University: 2004. 
Dillenbourg, P. M. dkk, The evolution of research on collaborative learning. Dalam E. Spada \& P. Reiman (Eds.), Learning in humans and machine: Towards an interdisciplinary learning science. Oxford: Elsevier. 1996.

Draft PISA Collaborative Problem Solving Framework 2015.

Gordon, Edward E. Peer Tutoring: A Teacher's Resource Guide. Maryland: R\&L Education. 2005.

Griffin, P., McGaw, B., \& Care, E. (Eds.). Assessment and Teaching of 21st Century Skills. Springer: Dordrecht. OECD. 2013.

$\mathrm{Gu}$, Xiaoqing dkk.an Intervention Framework Designed to Develop the Collaborative Problem-Solving Skills of Primary School Students. New York: Springer. 2015.

Hogan, K. Thinking Aloud Together: a Test of an Intervention to Foster Students' Collaborative Scientific Reasoning. Journal of Research in Science Teaching, Vol. 36, No. 10 (1999), 1085-1109.

Institute Titian Perdamaian. Konflik Horisontal di Indonesia. Jakarta: Institute Titian Perdamaian. 2011.

Johnson, R. T. dan Johnson, D. W. An Overview of Cooperative Learning. Baltimore: Brookes Press. 1994.

Korkmaz O. A Validity and Reliabilitu Study of the Online Cooperative Learning Attitude Scale (OCLAS). Journal Computers \& Education. Vol. 59. No. 4. 2012. 1162-1169.

Lai, Emily R. Collaboration: A Literature Review. Pearson's Research Reports. 2011.

Marzano, R.J. Dimension of Thingking: a Framework of Curriculume and Instruction. Alexandria: The Association for Supervision and Curriculume Development. 1988.

Mayer, R.E. "Problem solving", in Eysenck, M.W. (ed.), The Blackwell Dictionary of Cognitive Psychology, Blackwell: Oxford Press. 1990. 
Nesta. Solve! Making the Case for Collaborative Problem Solving. London: SB Victoria Embankment. 2017.

OECD (2010), PISA 2012 Field Trial Problem Solving Framework, http://www.oecd.org/dataoecd/8/42/46962005.pdf

Rowe, Helga A. H. Problem Soving and intelligence. Hillsdale: Erlbaum. 1985.

Sanders, Jennifer dan Damron, Rebecca L. They're All Writers: Theacing Peer Tutoring in the Elementary Writing Center. New York: Teacers College Pers. 2017.

Scardamalia, M. dkk. the CSILE Project: Trying to Bring the Classroom into World 3. In k. Mcgilly (ed.), Classroom Lessons: Integrating Cognitive Theory and Classroom Practice, (pp. 201-228). Cambridge: MIT Press. 1994.

Scoular, Claire dkk. A Generalised Approach to Scoring Students Collaboration in Online: Game Environments. Proceedings of the European Conference on Games Based Learning. Academic Conferences \& Publishing International Ltd. 2016, 584.

Scoular, Claire dkk. Designs for Operationalizing Collaborative Problem Solving for Automated Assessment. Journal of Educational Measurement, Vol. 54, No. 1. 2017.

Schreiber \& Asner-self. Educational Research : Interrelationship of Questions, Sampling, Design, and Analysis. USA: John Wiley \& Sons Inc. 2011.

Slavin, R.E. Instructional Based on Cooperative Learning. New York: John Hopkins University Press. 1995.

Wahid Institute. Buku Laporan Riset Intoleransi dan Radikalisme di 4 Wilayah Wahid Institute. Jakarta: Wahid Institute. 2016.

Wiley, Hilda Ives. Collaborative Problem-Solving Teams: The Relationship between Team Effectiveness And Teacher Attitudes, Beliefs, And Concerns, Tesis. The University Of Minnesota: 2006. 
Copyright (C) 2019 Journal Dirasah: Vol. 2, No. 2, Agustus 2019, p-ISSN: 2615-0212, e-ISSN; 2621-2838

\section{Copyright rests with the authors}

Copyright of Jurnal Dirasah is the property of Jurnal Dirasah and its content may not be copied or emailed to multiple sites or posted to a listserv without the copyright holder's express written permission. However, users may print, download, or email articles for individual use.

https://ejournal.iaifa.ac.id/index.php/dirasah

Dirasah, Vol. 2, No. 2, Agustus 2019 